\title{
Cortisol and Quality of Life Responses to Endurance Versus Resistive Exercises in Young Depressed Elderly
}

\author{
HALA M. EZZ-ELDIN, Ph.D.*; HANY F.E.M. ELSISI, Ph.D.*; AHMED S. MOHAMED, M.D.** and \\ ELSHAIMAA E. ALY, M.Sc.* \\ The Department of Cardiovascular/Respiratory Disorder and Geriatrics, Faculty of Physical Therapy, Cairo University* and \\ The Department of Psychiatry, Faculty of Medicine, Ain Shams University**
}

\begin{abstract}
Objective: To compare the effect of endurance versus resistive exercise on cortisol and its reflect on quality of life and depression scale in young depressed elderly.

Background: Exercise has been suggested to be a viable treatment for depression. This study compared the effect of endurance versus resistive exercise on cortisol and its reflect on quality of life and depression scale in young elderly in order to help elderly to be more active.

Subject and Methods: Thirty subjects (13 men, 17 women) were randomly assigned into two groups equal in number. Group (A) Fifteen subjects ( 7 men, 8 women) received Moderate intensity endurance (aerobic) exercise (50 to 70 ) \% of their maximum heart rate. Group (B) Fifteen subjects (6 men, 9 women) received resistance exercise composed of 6 stations of weight lifting with moderate intensity (30\% to $40 \%$ of 1 $\mathrm{RM}$ for upper body exercises and $50 \%$ to $60 \%$ of $1 \mathrm{RM}$ for lower body exercise). The program duration for both groups was 3 times/week for 12 weeks.
\end{abstract}

Results: Showed that 12 weeks of endurance or resistance exercise for depressed young elderly subjects caused a statistical significant improvement in Hamilton Depression Scale (16.86\% for Group A and $17.97 \%$ for Group B) and Older People Quality of Life Questionnaire (29.94\% for Group A and $20.37 \%$ for Group B) and a significant decrease in cortisol level (20.81\% for Group A and $15.6 \%$ for Group B) at the end of rehabilitation program with the favor of aerobic regarding cortisol level and quality of life. On the other hand resistive exercise has more effect on Hamilton Depression Scale.

Conclusions: Both endurance and resistance exercise are effective non-pharmacological adjuvant treatment for depression and improvement of quality of life in young elderly.

Key Words: Depression -Young elderly - Aerobic exercise Resistance exercise - Quality of Life.

Correspondence to: Dr. Hala M. Ezz-Eldin, The Department of Cardiovascular/Respiratory Disorder and Geriatrics, Faculty of Physical Therapy, Cairo University

\section{Introduction}

DEPRESSION is a state of low mood and aversion to activity or apathy that can affect a person's thoughts, behavior, feelings and sense of wellbeing [1].

Depression refers to a wide range of mental health problems characterized by the absence of a positive affect (a loss of interest and enjoyment in ordinary things and experiences), persistent low mood and a range of associated emotional, cognitive, physical and behavioral symptoms [2].

A person having a depressive episode usually exhibits a very low mood, which pervades all aspects of life, and an inability to experience pleasure in activities that were formerly enjoyed. In severe cases, depressed people may have symptoms of psychosis. These symptoms include delusions or, less commonly, hallucinations, usually unpleasant. Other symptoms of depression include poor concentration and memory, withdrawal from social situations and activities, reduced sex drive, and thoughts of death or suicide [3].

World Health Organization (WHO) set 50 as the beginning of old age. At the same time, the WHO recognized that the developing world often defines old age, not by years, but by new roles, loss of previous roles, or inability to make active contributions to society [4]

In general, quality of life (QoL or QOL) is the perceived quality of an individual's daily life, that is, an assessment of their well-being. This includes all emotional, social, and physical aspects of the individual's life [5]. Depressive disorders are associated with significant impairment in (QoL) [6]. 
Cortisol is a steroid hormone, in the glucocorticoid class of hormones. It is released in response to stress and low blood-glucose concentration. Mild to moderate hyperactivity of the HPA axis resulting in increased plasma cortisol is observed in 30-50\% of depressed subjects. Hypercortisolemia can be accompanied by low plasma cortisol levels as well [7]

Exercise can lead to a greater quality of life, with the absence of unwanted side effects from medication. It has been shown that exercise can reduce the incidence of older adults becoming depressed by up to $20 \%$. Both aerobic and resistance based exercise have been shown to have a positive effect on older adults suffering depression [8].

There are numerous performance benefits of aerobic exercise; increased storage of energy molecules such as fats and carbohydrates within the muscles, allowing for increased endurance, neovascularization of the muscle sarcomeres to increase blood flow through the muscles. Also, aerobic exercise can delay osteoporosis as there is an increase in muscle mass, a loss of fat and an increase in bone density [9]

The benefits of resistance exercise extend beyond muscle and tissue growth and include increases in muscle mass and bone density, alterations in neurobiological systems relevant to mental health and anxiety-related outcomes (e.g., cortisol and the HPA axis) [10].

The benefits of the regular practice of resistance exercises in the classical studies point benefits such as: Decrease of body adiposity, increase of muscle strength, increase of the individual myocyte size, decrease of the number of falls, increase of bone mineral density, improvement of the glycolized hemoglobin response, increase of functional capacity [11]

Exercise could improve depression and QoL through different mechanisms. In the Psychological domain, exercise may improve self-esteem selfefficacy and self-concept and promote general well-being [12].

\section{Subjects and Methods}

Thirty young elderly subjects (13 men, 17 women) with depression were included in this study. They were recruited from Psychiatry Outpatient Clinic at Psychiatry Department at ElDemerdash Hospital Ain Shams University. The practical work of the study was carried out in the period starting from December 2015 till October 2016.

\section{Inclusion criteria:}

All subjects have been selected from both sexes (women and men). They were between 60-70 years old. They were medically stable and apparently healthy. They had positive result of depression by Hamilton Depression Rating Scale a score of 20 or higher.

\section{Exclusion criteria:}

All subjects who complained from severe orthopedic abnormalities, visual or hearing problems that interfere with performing the program, severe memory problems as Alzheimer's disease, uncontrolled systemic arterial hypertension, noncompensated diabetes mellitus, severe arrhythmia and acute myocardial infarction were excluded from the study.

Subjects were randomly assigned to two groups equal in number:

- $\operatorname{Group}(A)$ : Fifteen subjects ( 7 men, 8 women) received moderate intensity endurance exercise (50 to 70 )\% of their maximum heart rate 3times/week for 12 weeks [13].

- $\operatorname{Group}(B)$ : Fifteen subjects (6 men, 9 women) received resistance exercise which composed of 6 stations of weight lifting. The resistance or weight lifted was moderate, which is defined as $30 \%$ to $40 \%$ of $1 \mathrm{RM}$ for upper body exercises and $50 \%$ to $60 \%$ of $1 \mathrm{RM}$ for lower body exercises [14].

\section{Evaluation procedures:}

\section{1-Psychological assessment of depression:}

By Hamilton Depression Scale which was a multiple item questionnaire used to provide an indication of depression and as a guide to evaluate recovery. Initially considered the "Gold Standard" for rating depression in clinical research, it was criticized as a test instrument for clinical practice in part because it places more emphasis on insomnia than on suicide ideas and gestures [15]

\section{2- Blood testing for cortisol level:}

The cortisol blood test measured the level of cortisol in the blood. The test was done to check for increased or decreased cortisol production. Cortisol is a steroid (glucocorticoid) hormone produced by the adrenal gland [16]

\section{3-Six-minutes walk test:}

The 6MWT was widely used to assess functional capacity and prognosis. It can also be used with 
different objectives: To predict aerobic capacity, or as a performance test to measure the response to different rehabilitation interventions encountered in everyday life, before and after intervention [1]

\section{4- Older Peoples Quality of Life Questionnaire $(O P Q o L)$ :}

The OPQOL questionnaire consisted of 35 statements with the participant being asked to indicate the extent to which he/she agrees with every single statement by choosing one of five the possible options among "strongly disagree", "disagree", "neither agree nor disagree", "agree" and "strongly agree". Each of the five possible answers was given a score of 1 to 5 so that higher scores indicate a better QOL. The total score ranged from 35 (the worst possible QOL) to 175 (the best possible QOL). The 35 statements of the questionnaire consider the following aspects of QOL: Life overall (4 items, score range 4-20), health (4 items, 4-20), social relationships and participation (8 items, 8-40), independence, control over life and freedom (5 items, 5-25), home and neighborhood (4 items, 4-20), psychological and emotional wellbeing ( 4 items, 4-20), financial circumstances (4 items, 4-20), culture and religion (2 items, 2-10) [18]

Evaluation was done at the beginning of the study and re-evaluated after 12 weeks of training.

\section{Treatment procedures:}

Endurance exercise training program (Group A):

- Fifteen young elderly subjects participated in supervised endurance exercise in form of walking on treadmill. Maximum heart rate was predicted for each patient by subtract the age from 220 .

- Intensity of exercise: $50-60 \%$ (The maximum heart rate-resting heart rate) + resting heart rate (Karvonen formula) [19]

\section{Resistance exercise training program (GroupB):}

- Fifteen young elderly subjects participated in the supervised resistive exercise program using weights for twelve successive weeks.

- Intensity: Starting load was determined after the assessment of the load that individual can lift only for one time i.e. one repetition maximum (1RM). Training started at $30 \%$ to $40 \%$ of $1 \mathrm{RM}$ for upper body exercises and $50 \%$ to $60 \%$ of 1 RM for lower body exercises for two sets of ten repetitions and was increased to three sets as tolerated [20]

\section{Results}

Comparing the general characteristics of the subjects of both groups revealed that there was no significance difference between both groups in the mean age, weight, height, and BMI $(p>0.05)$ (Table 1).

Table (1): Descriptive statistics and $t$-test for the mean age, weight, height and BMI of group A and group B.

\begin{tabular}{|c|c|c|c|c|c|c|}
\hline & Group A & Group B & \multirow{2}{*}{ MD } & \multirow{2}{*}{$\begin{array}{c}t- \\
\text { value }\end{array}$} & \multirow{2}{*}{$\begin{array}{c}p- \\
\text { value }\end{array}$} & \multirow{2}{*}{ Sig } \\
\hline & $\mathrm{X} \pm \mathrm{SD}$ & $\mathrm{X} \pm \mathrm{SD}$ & & & & \\
\hline $\begin{array}{l}\text { Age } \\
\text { (years) }\end{array}$ & $64.4 \pm 2.52$ & $63.53 \pm 1.95$ & 0.87 & 1.04 & 0.3 & NS \\
\hline $\begin{array}{l}\text { Weight } \\
(\mathrm{kg})\end{array}$ & $92.13 \pm 4.12$ & $91.66 \pm 3.95$ & 0.47 & 0.31 & 0.75 & NS \\
\hline $\begin{array}{l}\text { Height } \\
(\mathrm{cm})\end{array}$ & $163.8 \pm 3.85$ & $162.6 \pm 2.92$ & 1.2 & 0.96 & 0.34 & NS \\
\hline $\begin{array}{l}\text { BMI } \\
\left(\mathrm{kg} / \mathrm{m}^{2}\right)\end{array}$ & $34.36 \pm 1.72$ & $34.68 \pm 1.6$ & -0.32 & -0.52 & 0.6 & NS \\
\hline $\begin{array}{l}\mathrm{Kg}: \text { Kilog } \\
\mathrm{X}: \text { Mean } \\
\mathrm{Cm}: \text { Centil }\end{array}$ & tre & & $\begin{array}{l}\text { SD } \\
\text { Sig }\end{array}$ & Stan & anti. & \\
\hline
\end{tabular}

Table (2): Statistical analysis of Pre and post treatment mean values of cortisol level of group A and B.

\begin{tabular}{lll}
\hline & \multicolumn{1}{c}{ Group A } & Group B \\
\hline $\begin{array}{l}\text { Pretreatment } \\
\quad \mathrm{X} \pm \mathrm{SD}\end{array}$ & $12.54 \pm 2.02$ & $12.24 \pm 1.93$ \\
Post treatment & $9.93 \pm 2.03$ & \\
$\mathrm{X} \pm \mathrm{SD}$ & & $10.33 \pm 1.87$ \\
$\mathrm{MD}$ & 2.61 & 1.91 \\
$t$-value & 15.19 & 13.92 \\
$p$-value & 0.0001 & 0.001 \\
Sig & $\mathrm{S} \downarrow$ & $\mathrm{S} \downarrow$ \\
$\%$ of change & 20.81 & 15.6 \\
\hline $\mathrm{X}:$ Mean. & & MD :Mean difference. \\
SD: Standard deviation. & & $t$-value :Paired $t$-value. \\
S : Significant. & & $p$-value: Probability value.
\end{tabular}

As shown in Table (2), The mean \pm SD cortisol level pre-treatment of group A was $12.54 \pm 2.02$ $\mathrm{g} / \mathrm{d}$ and that post treatment was $9.93 \pm 2.03 \mathrm{~g} / \mathrm{d}$ The mean difference between pre and post treatment was $2.61 \mathrm{~g} / \mathrm{d}$ and the percent of change was $20.81 \%$. There was a significant decrease in the cortisol level in group A post treatment compared with pre-treatment $(p=0.0001)$. There was a significant decrease in the cortisol level in group A post treatment compared with pre-treatment $(p=0.0001)$.

The mean \pm SD cortisol level pre-treatment of group B was $12.24 \pm 1.93 \mathrm{~g} / \mathrm{d}$ and that post treatment was $10.33 \pm 1.87 \mathrm{~g} / \mathrm{d}$ The mean difference between pre and post treatment was $1.91 \mathrm{y} / \mathrm{d}$ hand the percent of change was $15.6 \%$. There was a significant decrease in the cortisol level in group B post treatment compared with pre-treatment $(p=0.0001)$. 
Table (3): Statistical analysis of Pre and post treatment mean values of Hamilton Depression Scale of group A and $\mathrm{B}$.

\begin{tabular}{|c|c|c|}
\hline & Group A & Group B \\
\hline $\begin{array}{l}\text { Pretreatment } \\
\qquad \mathrm{X} \pm \mathrm{SD}\end{array}$ & $20.93 \pm 2.71$ & $21.53 \pm 2.69$ \\
\hline $\begin{array}{l}\text { Post treatment } \\
\mathrm{X} \pm \mathrm{SD}\end{array}$ & $17.4 \pm 2.19$ & $17.66 \pm 1.91$ \\
\hline $\mathrm{MD}$ & 3.53 & 3.87 \\
\hline$t$-value & 14.94 & 12.01 \\
\hline$p$-value & 0.0001 & 0.0001 \\
\hline Sig & $S \downarrow$ & $S \downarrow$ \\
\hline$\%$ of change & 16.86 & 17.97 \\
\hline $\begin{array}{l}\text { X : Mean } \\
\text { SD:Standard deviation } \\
S \text { : Significant }\end{array}$ & & $\begin{array}{l}\text { an difference } \\
\text { bability value } \\
\text { ed } t \text {-value }\end{array}$ \\
\hline
\end{tabular}

As shown in Table (4), the mean \pm SD Hamilton Depression Scale pre-treatment of group A was $20.93 \pm 2.71$ and that post treatment was $17.4 \pm 2.19$. The mean difference between pre and post treatment was 3.53 and the percent of change was $16.86 \%$. There was a significant decrease in the Hamilton Depression Scale in group A post treatment compared with pre-treatment $(p=0.0001)$.

The mean \pm SD Hamilton Depression Scale pre-treatment of group B was $21.53 \pm 2.69$ and that post treatment was $17.66 \pm 1.91$. The mean difference between pre and post treatment was 3.87 and the percent of change was $17.97 \%$. There was a significant decrease in the Hamilton Depression Scale in group B post treatment compared with pre-treatment $(p=0.0001)$.

Table (4): Statistical analysis of Pre and post treatment mean values of OPQOL of group $\mathrm{A}$ and $\mathrm{B}$.

\begin{tabular}{lll}
\hline & \multicolumn{1}{c}{ Group A } & Group B \\
\hline $\begin{array}{l}\text { Pretreatment } \\
\mathrm{X} \pm \text { SD }\end{array}$ & $81.06 \pm 15.75$ & $86.4 \pm 12.69$ \\
Post treatment & $105.33 \pm 13.94$ & $104 \pm 11.68$ \\
$\quad \mathrm{X} \pm \mathrm{SD}$ & & \\
$\mathrm{MD}$ & -24.27 & -17.6 \\
$t$-value & -10.45 & 12.01 \\
$p$-value & 0.0001 & 0.0001 \\
Sig & $\mathrm{S} \uparrow$ & $\mathrm{S} \uparrow$ \\
$\%$ of change & 29.94 & 20.37 \\
\hline $\mathrm{X} \quad:$ Mean. & & \multicolumn{2}{c}{ MD : Mean difference. } \\
SD : Standard deviation. & $t$-value: Paired $t$-value. \\
$p$-value: Probability value. & \multicolumn{2}{c}{$:$ Significant. }
\end{tabular}

As shown in Table (4), the mean \pm SD OPQOL pre-treatment of group A was $81.06 \pm 15.75$ and that post treatment was $105.33 \pm 13.94$. The mean difference between pre and post treatment was -24.27 and the percent of change was $29.94 \%$. There was a significant increase in the OPQOL in group A post treatment compared with pre-treatment $(p=0.0001)$.
The mean \pm SD OPQOL pre-treatment of group $B$ was $86.4 \pm 12.69$ and that post treatment was $104 \pm 11.68$. The mean difference between pre and post treatment was -17.6 and the percent of change was $20.37 \%$. There was a significant increase in the OPQOL in group B post treatment compared with pre-treatment $(p=0.0001)$.

\section{Discussion}

Thirty young elderly subjects with depression symptoms, who agreed and consented to participate in this study, were recruited from psychiatry outpatient clinic at psychiatry department at ElDemerdash hospital Ain Shams University.

Subjects in Group A have received endurance exercise in form of walking on treadmill 3 days per week for 12 successive weeks and duration of each session was 30-40 minutes. Subjects in Group $\mathrm{B}$ have received resistance exercise using weights 3 days per week for 12 successive weeks.

This current study demonstrated that 12 weeks of endurance exercise for depressed young elderly patients (Group A) caused a statistical significant improvement $(p<0.05)$ in Hamilton Depression Scale with percentage (16.86\%) and Older People Quality of Life Questionnaire with percentage $(29.94 \%)$ and a significant decrease in cortisol level with percentage (20.81\%) at the end of rehabilitation program.

Pilu et al., [21] performed a randomized trial with naturalistic control on a small sample of 30 depressed women [aged between 40 and 60 years old], undergoing and not responders to antidepressant therapy, randomized either to the treatment (one hour 2 weekly supervised aerobic exercise session plus usual antidepressant) or control group (antidepressant alone) during 8 months, assessed with HAM-D. Only the treatment group showed significant reduction in HAM-D scores $(p<0.0001)$, while controls didn't improve significantly $(p=0.28)$.

This current study demonstrated that 12 weeks of resistance exercise for depressed young elderly patients (Group B) has caused a statistical significant improvement $(p<0.05)$ in Hamilton Depression Scale with percentage $(17.97 \%)$ and Older People Quality of Life Questionnaire with percentage $(20.37 \%)$ and a significant decrease in cortisol level with percentage (15.6\%) at the end of rehabilitation program.

The results of this study are in consistent with O'Connor et al., [22] who reported that at least four 
studies have examined the effects of resistance training on depression levels in clinically depressed individuals and concluded that there was sufficient evidence to support resistance training as an effective intervention for reducing depression symptoms in adults with depression.

Singh et al., [23] have researched the effects of resistance training on depression in elderly individuals. In a classic study, they found that more than $80 \%$ of the depressed elders who performed three weekly sessions of resistance training were no longer clinically depressed after just 10 week of exercise.

Studies have shown that other interventions in depression such as electroconvulsive therapy and pharmacological treatments improve quality of life of depressed patients [24].

In addition, Brenes et al., [25] compared aerobic exercise and antidepressant (sertraline) in depressed elders and concluded that both interventions improve QoL without any differences between them.

Also, Langlois et al., [26] observed that three months of aerobic training in older adults resulted in significant improvement in physical capacity and cognitive performance as well as quality of life.

Coincided with our study, previous laboratory researches suggested that a combined treatment with exercise plus antidepressant produced significant increases of brain derived neurotropic factor level whereas antidepressant alone failed [27]

The results of this study are in consistent with Papasavvas et al., [28] who reported that moderateintensity aerobic exercise promoted large, significant reductions in depressive symptoms, while no significant effect was found for vigorous exercise.

The results of this study also came in agreement with Matthew et al., [29] who reported that resistive exercise training significantly reduced depressive symptoms by a heterogeneous mean effect. The effect of exercise is equivalent to a clinical effect of $7.5 \%$ beyond chance for patients exposed to exercise, hypothetically benefiting approximately 790 of the 10534 patients included in the reviewed trials.

Mausbach et al., [30] found that depressive symptom reductions could be expected to occur for at least 1 patient for every 6 chronically ill patients experiencing depressive symptoms who would engage in exercise training.
Copeland et al., [31] studied 30 healthy trained elderly aged between 60 and 69. Cortisol concentration significantly decreased in the participants during endurance and resistance exercises while lactate levels significantly increased after resistance exercise that was consistent with the results of our study.

\section{Conclusions:}

Both endurance and resistance exercise are effective non-pharmacological adjuvant treatment for depression and improvement of quality of life in young elderly.

\section{References}

1- American Psychiatric Association (APA).: Diagnostic and Statistical Manual of Mental Disorders, Fifth Edition (DSM-5), 2013.

2- National Institute for Health and Clinical Excellence (NICE).: The treatment and management of depression in adults (update), 2009.

3- DELGADO P.L. and SCHILLERSTROM J.: Cognitive Difficulties Associated with Depression: What Are the Implications for Treatment? psychiatric times, 26 (3), 2009.

4- World Health Organization "WHO": Definition of an older or elderly person, 2016.

5- BOTTOMLEY and ANDREW : The Cancer Patient and Quality of Life. The Oncologist., 7 (2): 120-125, 2015.

6- ROCHA N.S., POWER M.J., BUSHNELL D.M. and FLECK M.P.: Is there a measurement overlap between depressive symptoms and quality of life? Comprehensive Psychiatry, 50: 549-555, 2009.

7- VYTHILINGAM M., GILL J.M., LUCKENBAUGH D.A. GOLD P.W.,COLLIN C. and BONNE O.: Low early morning plasma cortisol in posttraumatic stress disorder is associated with co-morbid depression but not with enhanced glucocorticoid feedback inhibition, Psychoneuroendocrinology, 35 (3): 442-450, 2010.

8- BARBOUR K.A. and BLUMENTHAL J.A.: Exercise training and depression in older adults. Neurobiology of Aging., 26 (1): 119-123, 2005.

9- HEBESTREIT HELGE and BAR-OR ODED: The Young Athlete. Blackwell Publishing Ltd. p. 443, 2014.

10- CREWTHER B.T., COOK C., CARDINALE M., WEATHERBY R.P. and LOWE T.: Two emerging concepts for elite athletes, The short-term effects of testosterone and cortisol on the neuromuscular system and the doseresponse training role of these endogenous hormones, Sports. Med., 41, 103-123, 2011.

11-SAKKAS G.K., MULLIGAN K., DASILVA M., DOYLE J.W., KHATAMI H., SCHLEICHT, et al.: Creatine fails to augment the benefits from resistance training in patients with HIV infection: A randomized, double-blind, placebocontrolled study, 2009.

12- GALPER D.I., TRIVEDI M.H., BARLOW C.E., DUNNAL and KAMPERT J.B.: Inverse association between physical inactivity and mental health in men and women. 
Medicine \& Science in Sports \& Exercise, 38: 173-178, 2006.

13- BRONSTAD E., TJONNA A.E., ROGNMO O., et al.: Aerobic exercise training improves right and left ventricular systolic function in patients with COPD, 10: 300-6, 2013.

14- RANDY W. BRAITH and KERRY J. STEWART: Resistance Exercise Training Its Role in the Prevention of Cardiovascular Disease., 113: 2642-2650, 2006.

15- BAGBY R.M., RYDER A.G., SCHULLER D.R. and MARSHALL M.B.: The Hamilton Depression Rating Scale: Has the gold standard become a lead weight?. American Journal of Psychiatry, 161 (12): 2163-77, 2004.

16- STEWART P.M., MELMED S., POLONSKY K.S., LARSEN P.R. and KRONENBERG H.M.: Williams Textbook of Endocrinology. 13 th ed. Philadelphia, PA: Elsevier Saunders. Chap., 15, 2016.

17- JANNIS V. PAPATHANASIOU, ELENA ILIEV and BLAGOI MARINOV: Six-Minute Walk Test: An Effective and Necessary Tool in Cardiac Rehabilitation Hellenic J. Cardiol., 54: 126-130., 2013.

18- BILOTTA C., BOWLING A., NICOLINI P., CASÉ A. and VERGANI C.: Quality of life in older outpatients living alone in the community in Italy. Health \& Social Care in the Community, 20: 32-41, 2012.

19- ALBINET C.T., BOUCARD G., BOUQUET C.A. and AUDIFFREN M.: Increased heart rate variability and executive performance after aerobic training in the elderly. Eur. J. Appl. Physiol., 109: 617-624, 2010.

20- MARCHESE ROSEMARY and HILL ANDREW: The essential guide to fitness: For the fitness instructor. Sydney, NSW: Pearson Australia, p. 135, 2011.

21- PILU A., SORBA M., HARDOY M.C., et al.: Efficacy of physical activity in the adjunctive treatment of major depressive disorders: Preliminary results. Clin. Pract Epidemiol., Ment. Health, 3: 8, 2007.

22- O'CONNOR P.J., HERRING M.P. and CARAVALHO A.: Mental health benefits of strength training in adults. Am. J. Lifestyle. Med., 4: 377-396, 2010.

23- SINGH N.A., STAVRINOS T.M., SCARBEK Y., GALAMBOS G., LIBER C. and SINGH M.A.: A randomized controlled trial of high versus low intensity weight training versus general practitioner care for clinical depression in older adults. The Journals of Gerontology. Series A, Biological Sciences and Medical Sciences, 60 (6): 768-776, 2005.

24- ANTUNES P.B. and FLECK M.P.: Clinical outcomes and quality of life in patients submitted to electroconvulsive therapy. The Journal of ECT, 25: 182-185, 2009.

25- BRENES G.A., WILLIAMSON J.D., MESSIER S.P., REJESKI W.J., PAHOR M., et al.: Treatment of minor depression in older adults: A pilot study comparing sertraline and exercise. Aging \& Mental Health, 11: 61-68, 2007.

26- LANGLOIS F., CHASS ${ }^{\prime} E . K .$, DUPUIS G., KERGOAT M. and BHERER L.: "Benefits of physical exercise training on cognition and quality of life in frail older adults", Journals of Gerontology B, Vol. 68, No. 3, pp. 400-404, 2013

27- RUSSO-NEUSTADT A.A., ALEJANDRE H., GARCIA C., IVY A.S. and CHEN M.J.: Hippocampal brain-derived neurotrophic factor expression following treatment with reboxetine, citalopram, and physical exercise. Neuropsychopharmacology, 29 (12): 2189-99, 2004.

28- PAPASAVVAS T., BONOW R.O., ALHASHEMI M. and MICKLEWRIGHT D.: Depression symptom severity and cardiorespiratory fitness in healthy and depressed adults: A systematic review and meta-analysis. Sports. Med., 46: 219-30, 2016.

29- MATTHEW P., TIMOTHY W., PATRICK J., O'CONNOR Ph.D. and RODNEY K.: A Systematic Review and Metaanalysis of Randomized Controlled Trials Effect of Exercise Training on Depressive Symptoms Among Patients With a Chronic Illness, Arch. Intern. Med., 172 (2): 101111,2012

30- MAUSBACH B.T., CHATTILLION E.A., MOORE R.C., ROEPKE S.K., DEPP C.A. and ROESCH S.: Activity restriction and depression in medical patients and their caregivers: A meta-analysis. Clin. Psychol. Rev., 31 (6): 900-908, 2011.

31- COPELAND J.L., CONSITT LA. and TREMBLA M.S.: Hormonal Responses to Endurance and Resistance Exercise in Females Aged 19-69 Years. Journal of Gerontology: Biological Sciences, 57 (4): 158-165, 2002. 


\section{استجابة الكورتيزول وكفاءة الحياة الى تمرينات التحمل مقابل تمرينات المقاومة في كبار السين}

مقارنة تأثيرتمرينات التحمل مقابل تمرينات المقاومة على مستوى الكوتيزول وانعكاسها على نوعية الحياة ومقياس الاكتئاب فى المسنين.

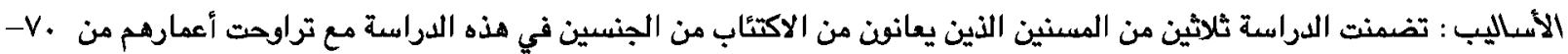

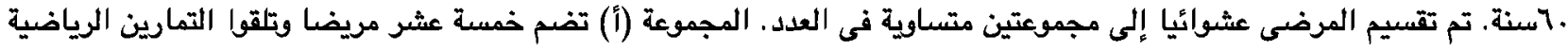

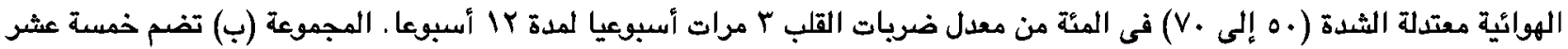

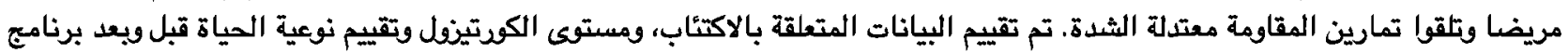

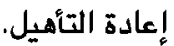

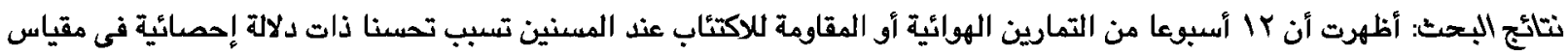

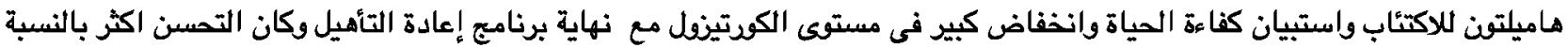
اللكرتيزول واستبيان كةاءة الحياة في مجموعة التمارين الهوائية بينما كان اكثر حدوثا بالنسبة لاستبيان الاكتئاب في مجموعة تمارين المقاومة الاستتاج: ممارسة كل من تمرينات التحمل وتمرينات المقاومة له دوفعال كعلاج غير دوائى للاكتئاب وتحسين نوعية الحياة فى كبار السن. 